\title{
Some biological aspects of House sparrow (Passer domesticus niloticus) at Alexandria governorate
}

\author{
El- Danasory, M. A.;M. A. Mostafa, M. A.,Mohafez,and M. F. El- Sawy \\ Agric. Zoology and Nematology, Dep. Fac. Agric. Al- Azhar Univ. \\ Corresponding author: dr_ma_danasory@yahoo.com
}

\begin{abstract}
In Egypt during season 2015 the breeding biology of the house sparrow (Passer domesticus niloticus) was studied at Alexandria governorate in a new reclaimed land (Borg El- Arab district) and old land (Apies district) nearby buildings and field crops habitats. This study has shown that, the female of the house sparrow laying four broods annually during (March to July2015). During a season, average of clutch size was recorded with (4.5) and (4.2) eggs / nest nearby buildings and field crops habitats in new reclaimed land, while the average were recorded with (4.6) and (4.4) eggs / nest nearby buildings and field crops habitats in the old lands respectively. The average incubation period was $13.5 \& 13.9$ days in newly reclaimed and old lands respectively.
\end{abstract}

Key words: House sparrow, biological aspects.

\section{Introduction}

The house sparrow Passer domesticus (L.) is one of the familiar species that has followed man everywhere and is inseparable from human habitations (Turner 2003).It was considered as anagricultural pest species and caused substantial losses to wheat, sorghum, pearl millet and rice crops. (Brooks and Ahmed 1990) observed the nests in holes in the walls of houses and in thick bushes and trees. Dandapat et al. (2010) observed that the house sparrow lays five to six eggs, profusely dusted, speckled or blotched with black, brown or ash-grey on a blue-tinted or creamy white ground. The incubation period of all the birds varies around 10-12 days. ASLAN and YAVUZ (2010) determined the clutch and egg size variation, breeding success, and productivity of the house sparrow (Passer domesticus), in terms of clutch size and breeding attempts, and to evaluate variation in temperature, rainfall, and humidity in terms of breeding attempts and years, and their possible effects on given parameters of the species.

\section{Materials and Methods}

Some biological aspects of the house sparrow (Passer domesticus niloticus) were studies at Alexandria governorate, a total numbers of 40 nests of house sparrow were investigated in different habitats. The study aimed to determine (egg laying duration, clutch size, total number of eggs, incubation period /day and percentage of hatchability). Ten nestswere chosen randomly nearby buildings and field crops habitats at new reclaimed land (Borg El- Arab district) and old land (Apies district) at Alexandria governorate during 2015 breeding season, respectively. Nests were visited daily, when nestlings were about 10 days old, just before they became fledglings. The dates for in the different clutcheswere compared in all nests.

\section{Results}

\section{I-Nearby buildings:-}

\section{Egg laying duration}

Data in Table (1) and fig. (1), showed that, the female of Passer domesticus niloticus lay four broods during the breeding season in both, new reclaimed and old lands nearby buildings, the first brood begin from (8 - 12 Mar.) and from (18 - 24 Mar.) in new reclaimed and old lands. The second broods begin from (16 - 21 Apr.) and from (25 - 30 Apr.) in new reclaimed and old lands. On the other hand, the third broods begin from (28 May - 1 Jun.) and from (2 Jun. -12 Jun.) in the new reclaimed and old lands, while the fourth brood begin from (10 -20 Jul.) and from (819 Jul.) in new reclaimed and old lands, respectively.

Total no. of eggs and average no. of eggs / nest.

House sparrow female lay $(44-45),(45-47),(26$ $-32),(23-27)$, eggs with average $(4.4-4.5),(4.5-$ $4.7),(4.3-4.6)$ and $(4.6-4.5)$ eggs / nest in the first, second, third and fourth brood in new reclaimed and old lands, respectively.

\section{Incubation period (in days)}

House sparrow incubate it eggs, average of incubation period recorded with $(14.0,13.8,13.7$ and 
13.0) days in the first, second, third and fourth brood in new reclaimed land, while recorded with $(14.3,14.0$, 13.8 and 13.8)days in the old land during the first, second, third and fourth broods, respectively.

\section{Hatchability \%}

The Hatchability \% of House sparrow egg were (91.1 and 93.3), (90.9 and 91.3), (92.3 and 93.8) and (96.0 and 96.3) in new reclaimed and old lands during the first, second, third and fourth broods, respectively.

\section{П- Nearby field crops:-}

\section{Egg laying duration}

Data in Table (2) and fig. (2), showed that, the female of Passer domesticus niloticus lay four broods during the breeding season in both, new reclaimed and old lands nearby field crops, the first brood begin from (21Mar. - 25 Mar.) in both new and old lands. The second broods begin from (1May -5 May) and from (26 Apr. - 4 May) in new and old lands. On the other hand, the third broods begin from (10 Jun. -15 Jun.) in the new reclaimed land and from ( 7 Jun. -13 Jun.) in the old land, while the fourth brood begin from (17 Jul.
- 21 Jul.) and from (14 Jul. 22 Jul.) in new reclaimed and old lands, respectively.

Total no. of eggs and average no. of eggs / nest.

House sparrow female lay $(43-44),(31-44),(25-$ $30)$ and (26 -31), eggs with average $(4.3-4.4)$, (3.9$4.4),(4.2-4.3)$ and $(4.3-4.4)$ eggs / nest in the first, second, third and fourth brood in new reclaimed and old lands respectively.

\section{Incubation period (in days)}

House sparrow incubate it eggs, average of incubation period recorded with $(13.8,13.6,13.5$ and 13.2) days in the first, second, third and fourth brood in new reclaimed land, while recorded with (14.1, 13.8, 13.7 and 13.5) days in the old land during the first, second, third and fourth broods, respectively.

\section{Hatchability \%}

The Hatchability \% of House sparrow egg were (83.7 and 88.6), (87.1 and 90.9), (92.0 and 86.7) and (88.5 and 87.1) in new reclaimed and old lands during the first, second, third and fourth broods, respectively. 
Table 1. Some biological aspects of house sparrow (Passer domesticus niloticus) nearby building in new- reclaimed and old lands during season 2015 at Alexandria governorate.

\begin{tabular}{|c|c|c|c|c|c|c|c|c|c|c|c|c|}
\hline \multirow[b]{2}{*}{ Clutches } & \multicolumn{2}{|c|}{ No. of inspected nests } & \multicolumn{2}{|c|}{ Egg- laying duration } & \multicolumn{2}{|c|}{$\begin{array}{c}\text { Total No. of } \\
\text { Eggs }\end{array}$} & \multicolumn{2}{|c|}{$\begin{array}{l}\text { Av. No. of } \\
\text { Eggs / nest }\end{array}$} & \multicolumn{2}{|c|}{$\begin{array}{c}\text { Incubation } \\
\text { period (days) }\end{array}$} & \multicolumn{2}{|c|}{ Hatching $\%$} \\
\hline & $\begin{array}{c}\text { New } \\
\text { reclaimed } \\
\text { land }\end{array}$ & $\begin{array}{l}\text { Old } \\
\text { land }\end{array}$ & New reclaimed land & Old land & $\begin{array}{c}\text { New } \\
\text { reclaimed } \\
\text { land }\end{array}$ & $\begin{array}{l}\text { Old } \\
\text { land }\end{array}$ & $\begin{array}{c}\text { New } \\
\text { reclaimed } \\
\text { land }\end{array}$ & $\begin{array}{l}\text { Old } \\
\text { land }\end{array}$ & $\begin{array}{c}\text { New } \\
\text { reclaimed } \\
\text { land }\end{array}$ & $\begin{array}{l}\text { Old } \\
\text { land }\end{array}$ & $\begin{array}{c}\text { New } \\
\text { reclaimed } \\
\text { land }\end{array}$ & $\begin{array}{l}\text { Old } \\
\text { land }\end{array}$ \\
\hline First & 10 & 10 & 8 Mar. -12 Mar. & 18 Mar. - 24 Mar. & 44 & 45 & 4.4 & 4.5 & 14.0 & 14.3 & 91.1 & 93.3 \\
\hline Second & 10 & 10 & 16 Apr. - 21Apr. & 25 Apr. - 30 Apr. & 45 & 47 & 4.5 & 4.7 & 13.8 & 14.0 & 90.9 & 91.3 \\
\hline Third & 6 & 7 & 28 May - 1 Jun. & 2 Jun. - 12 Jun. & 26 & 32 & 4.3 & 4.6 & 13.7 & 13.8 & 92.3 & 93.8 \\
\hline Fourth & 5 & 6 & 10 Jul. -20 Jul. & 8 Jul. - 19 Jul. & 23 & 27 & 4.6 & 4.5 & 13.0 & 13.8 & 96.0 & 96.3 \\
\hline Total & 31 & 33 & & & 138 & 151 & 4.5 & 4.6 & 13.6 & 14.0 & 92.6 & 93.7 \\
\hline
\end{tabular}

Table 2. Some biological aspects of house sparrow (Passer domesticus niloticus) nearby crops in new- reclaimed and old lands during season 2015 at Alexandria governorate.

\begin{tabular}{|c|c|c|c|c|c|c|c|c|c|c|c|c|}
\hline \multirow[b]{2}{*}{ Clutches } & \multicolumn{2}{|c|}{ No. of inspected nests } & \multicolumn{2}{|l|}{ Egg- laying duration } & \multirow{2}{*}{$\begin{array}{l}\text { Total } \\
\text { Eggs } \\
\text { New } \\
\text { reclaimed } \\
\text { land }\end{array}$} & \multirow{2}{*}{$\begin{array}{c}\text { No.of } \\
\begin{array}{c}\text { Old } \\
\text { land }\end{array}\end{array}$} & \multicolumn{2}{|l|}{$\begin{array}{l}\text { Av. No. } \\
\text { Eggs / nest }\end{array}$} & \multicolumn{2}{|c|}{$\begin{array}{l}\text { Incubation } \\
\text { period (days) }\end{array}$} & \multicolumn{2}{|c|}{ Hatching \% } \\
\hline & $\begin{array}{l}\text { New } \\
\text { reclaimed } \\
\text { land }\end{array}$ & $\begin{array}{l}\text { Old } \\
\text { land }\end{array}$ & New reclaimed land & Old land & & & $\begin{array}{l}\text { New } \\
\text { reclaimed } \\
\text { land }\end{array}$ & $\begin{array}{l}\text { Old } \\
\text { land }\end{array}$ & $\begin{array}{l}\text { New } \\
\text { reclaimed } \\
\text { land }\end{array}$ & $\begin{array}{l}\text { Old } \\
\text { land }\end{array}$ & $\begin{array}{l}\text { New } \\
\text { reclaimed } \\
\text { land }\end{array}$ & $\begin{array}{l}\text { Old } \\
\text { land }\end{array}$ \\
\hline First & 10 & 10 & 21 Mar. -25 Mar. & 21 Mar. - 25 Mar. & 43 & 44 & 4.3 & 4.4 & 13.8 & 14.1 & 83.7 & 88.6 \\
\hline Second & 8 & 10 & 1 May - 5 May & 26 Apr. - 4 May & 31 & 44 & 3.9 & 4.4 & 13.6 & 13.8 & 87.1 & 90.9 \\
\hline Third & 6 & 7 & 10 Jun. - 15 Jun. & 7 Jun. - 13 Jun. & 25 & 30 & 4.2 & 4.3 & 13.5 & 13.7 & 92.0 & 86.7 \\
\hline Fourth & 6 & 7 & 17 Jul. -21 Jul. & 14 Jul. -22 Jul. & 26 & 31 & 4.3 & 4.4 & 13.2 & 13.5 & 88.5 & 87.1 \\
\hline Total & 30 & 34 & & & 125 & 149 & 4.2 & 4.4 & 13.5 & 13.8 & 87.8 & 88.3 \\
\hline
\end{tabular}




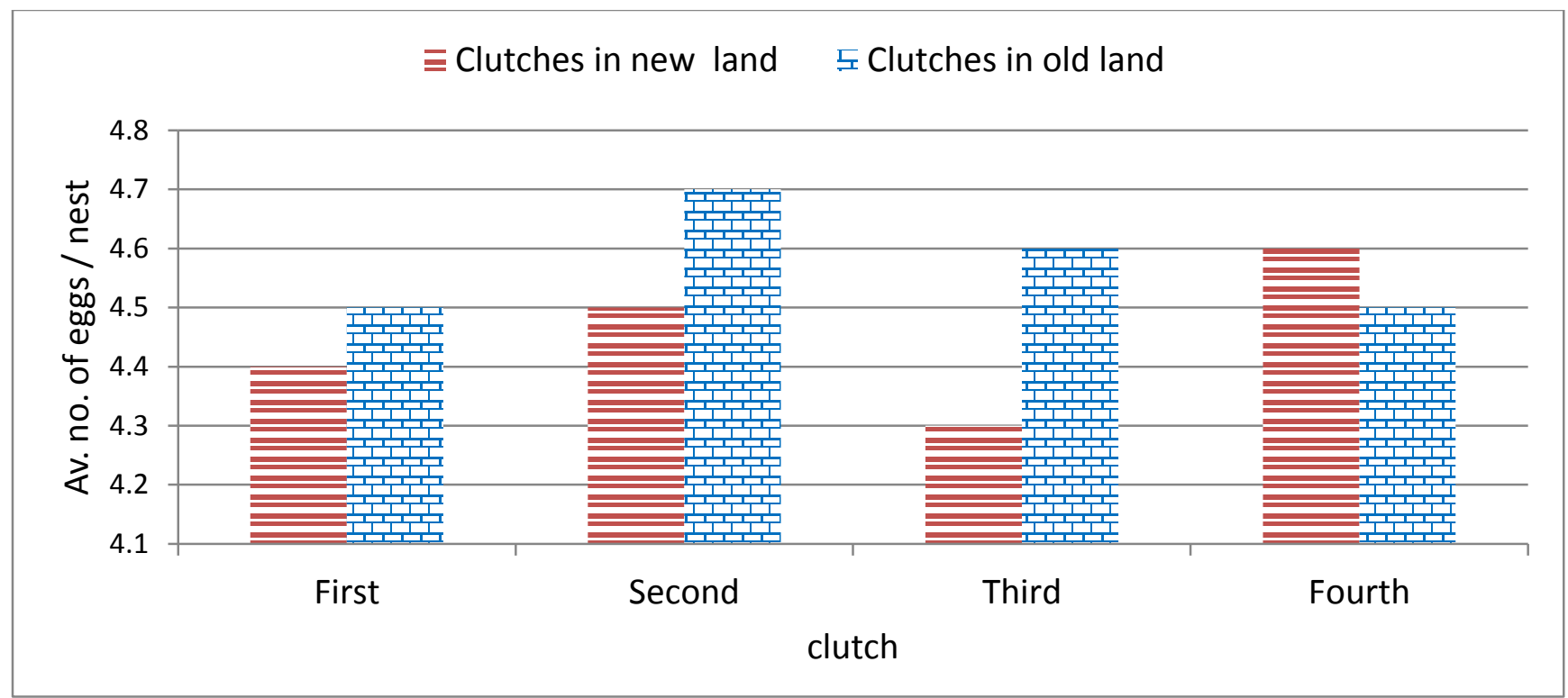

Fig. (1) Average of clutch size of house sparrow (Passer domesticus niloticus) nearby building during season 2015.

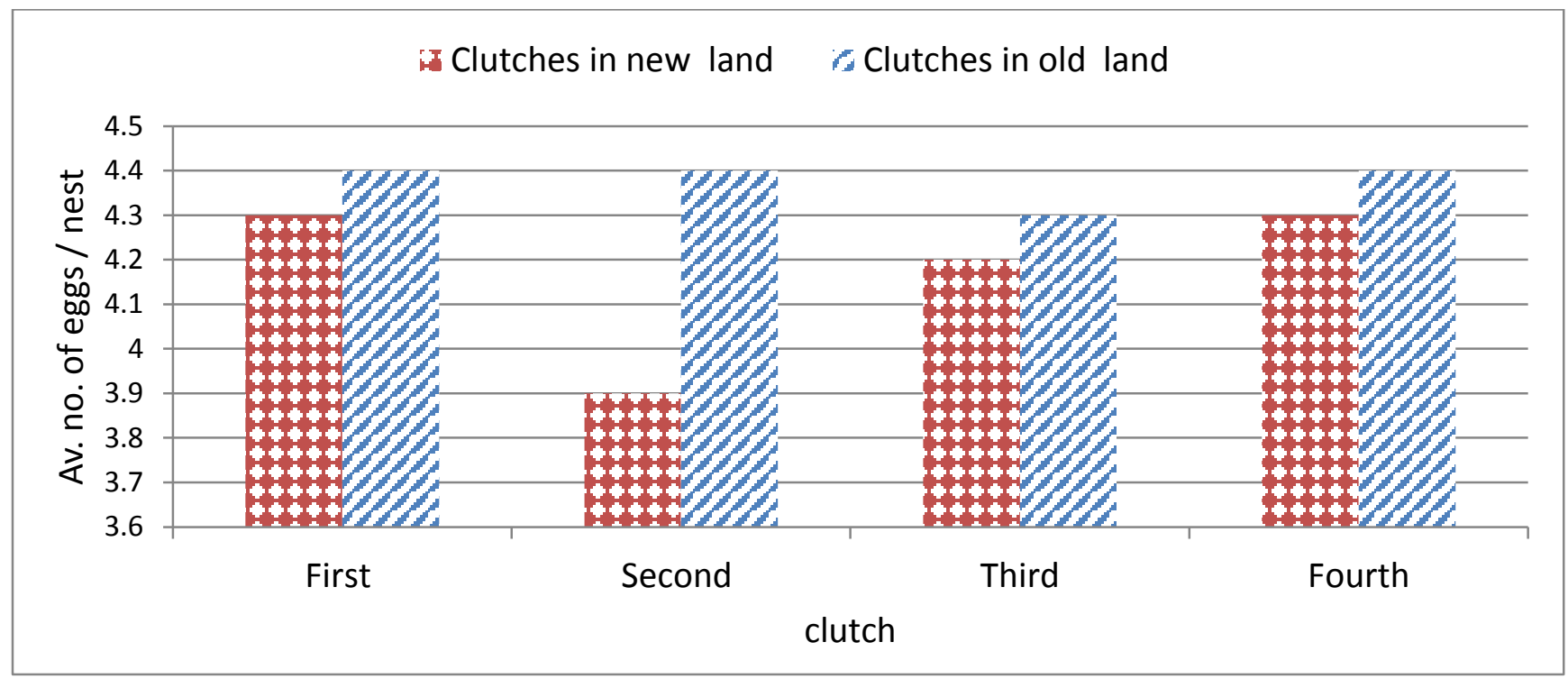

Fig. (2) Average of clutch size of house sparrow (Passer domesticus niloticus) nearby field crops during season 2015.

\section{Discussion}

These results agree with (Chopra et al. 2012) who reported that, the clutch size varied from 1 to 6 with a mean of $3.62 \pm 0.55$; clutch size of 4 was the most common in the 59 studied nests. Also (Soliman 1993) observed that, the clutch size generally ranged between 3.0 and 4.4 eggs / clutch. (Erdoğan and Kiziroğlu 1995), (Sıkı1992) mentioned that, the clutch size in Turkey ranges from 3-6 and 3-7 eggs, respectively, and the most common and most successful clutch size was 5 eggs per clutch. While (Khattab 1993) observed that, the type of habitat ecosystem considerably affected the breeding of house sparrow Passer domesticus niloticus whereas trees nearby buildings were most suitable site for breeding, while trees nearby field crops were lowest ones. This is similar to the results reached during our studies 2015.

\section{Reverences}

ASLAN, A. and YAVUZ, M. (2010). Clutch and egg size variation, and productivity of the house 
sparrow (Passer domesticus): effects of temperature, rainfall, and humidity. Turk J. Zool., Vol.34 (2010) 255-266

Brooks, J. E. and Ahmad, E. (1990). Pest birds of Pakistan: identification and distribution. Vertebrate Pest Management, a Training Manual, pag.173-180

Chopra, G.; Kumar, A. and Rai, D. (2012). Clutch size and egg Morphometric Parameters of House sparrow, Passer domesticus (Linnaeus, 1758) in District Kurukshetra, Haryana (India).Researcher; Vol.4 (6):56-61.

Dandapat, A.; Banerjee, D. and Chakraborty, D. (2010). The case of the disappearing house sparrow (Passer domesticus indicus). Veterinary World, 3(2): 97-100.

Erdoğan, A. and Kiziroğlu, İ. (1995). Brutbiologische Untersuchungenam Feld-Passer montanus und $P$. domesticus in Beytepe/Ankara.Orn. Verh. 25: 211218.

Khattab, M. M. (1993). Biological, Ecological and toxicological studies on harmful birds of agriculture land of Sharkia Govemorate. M.Sc. Thesis Fac. Agric., A1 - Azhar Univ. PP.199.

Sıkı, M. (1992). Ev Serçesi (Passer domesticus)'nin üreme biyolojisiüzerine araştırmalar. Doğa - Tr. J. of Zoology 16: 243-247.

Soliman, A.M.A. (1993). Studies on arthropods associated with the harmful birds and their nests at Kafr El- Sheikh Governorate. M. Sc.Thesis Faculty of Agriculture Zagazig University. pp. 176.

Turner, W. R. (2003). Study into house sparrow depletion in the U.K. Landscape, Urban Planning, 65, pp 149-166. 


\section{بعض السمات البيولوجية لطائر عصفور النيل الدورى (Passer domesticus niloticus) فى محافظة الأسكندرية}

محد عبدالعظيم محمد الدناصورى، مصطفى عبد اللطيف مصطفى أحمد، محد عبدالعال محمد محافظ ، محمود فوزى سعد الصاوى

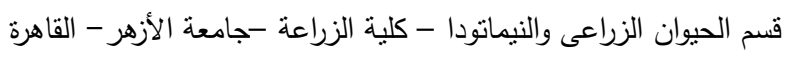

أجريت هذه الدراسة خلال موسم 10 • ب بمحافظة الأسكندرية بهدف دراسة بعض السمات البيولوجية لطائر عصفور النيل الدورى فى البيئه المصرية .

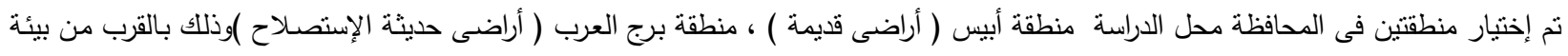

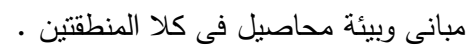
أوضحت النتائج أن أنثى عصفور النيل الدورى تضع أربع حضنات خلاد الموسم في الفنترة من مارس حتى يوليو خلال موسم الدراسة .

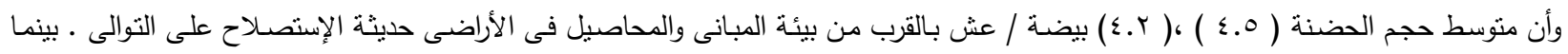

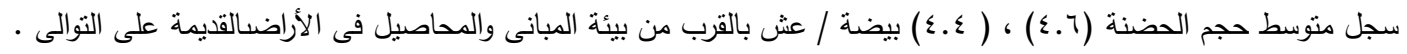

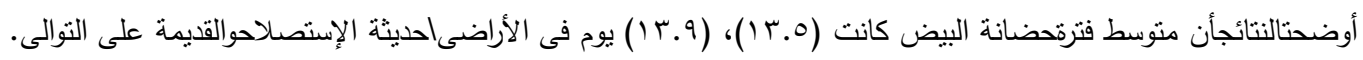

